\title{
18. INORGANIC GEOCHEMISTRY OF THE LEG 44 SEDIMENTS
}

\author{
I.O. Murdmaa and V.V. Gordeev, P.P. Shirshov Institute of Oceanology, USSR Academy of Sciences, Moscow \\ E.S. Bazilevskaya, Geological Institute, USSR Academy of Sciences, Moscow \\ and \\ E.M. Emelyanov, Atlantic Branch, P.P. Shirshov Institute of Oceanology, USSR Academy of Sciences, Kaliningrad
}

\section{INTRODUCTION}

We analyzed samples of sediment and sedimentary rock from DSDP Leg 44 for major ( $\mathrm{Fe}, \mathrm{Mn}, \mathrm{Ti}, \mathrm{Al}$ ) and minor $(\mathrm{Cu}, \mathrm{Zn}, \mathrm{Ni}, \mathrm{Cr})$ elements. Our purpose was to reveal the geochemical history and genesis of the main sediment types. We paid particular attention to possible enrichment of red or variegated layers in order to discover "metalliferous" sediments similar to those previously described from the Atlantic, Indian, and Pacific mid-oceanic ridges. Because of the proximity of Leg 44 and Leg 11 sites, we related our work to interpretation of the variegated claystones at Site 105 (Leg 11) by Lancelot et al. (1972).

Routine wet chemistry and atomic adsorption methods were applied. Wet geochemistry methods were used for most $\mathrm{Fe}, \mathrm{Mn}, \mathrm{Ti}$, and $\mathrm{CaCO}_{3}$ determinations. Atomic adsorption methods were used for minor elements, $\mathrm{Al}, \mathrm{Fe}$ (in part), and $\mathrm{Mn}$ (in part). We determined the different forms of iron in sediments by the following methods. $\mathrm{Fe}^{+2}$ (soluble) was detected by titration with bi-chromate after the sample was boiled for five minutes in HCL $(5: 100)$. Total $\mathrm{Fe}^{+2}$ was determined by the same method of titration after the sample was decomposed in a mixture of $\mathrm{HF}$ and $\mathrm{H}_{2} \mathrm{SO}_{4}$. Iron in $\mathrm{FeS}_{2}$ was determined in the insoluble residue after evaporation of the $\mathrm{HF}$ and $\mathrm{H}_{2} \mathrm{SO}_{4}$ mixture. Free oxides of $\mathrm{Fe}$ ("soluble" $\mathrm{Fe}^{+3}$ ) were determined photometrically in mercury light. We used the Tamm oxalate reagent with $\mathrm{PH}=3.25$ which consisted of $12.61 \mathrm{~g}$ of oxalic acid and $24.9 \mathrm{~g}$ of ammonium oxalate per one liter of water. We assumed that amorphous and poorly crystalline hydrated forms of $\mathrm{Fe}_{2} \mathrm{O}_{3}$, including dispersed hydrohematite and hydrogoethite, were dissolved by the reagent, whereas crystalline goethite, hematite, and magnetite, and the iron silicates were not affected.

The concentrations are expressed as weight percentages or ppm $\left(10^{-4}\right)$ on dried $\left(+100^{\circ} \mathrm{C}\right)$ samples. Seawater salts were not removed.

Analyses were carried out in laboratories of the P.P. Shirshov Institute of Oceanology and Geological Institute of the USSR Academy of Sciences.

\section{RESULTS}

Iron: The iron content in the sediments ranges from 0.09 per cent to 16.53 per cent (Table 1, Figure 1). The single maximum value occurred in a sideritic interbed. Except for this bed the iron content does not exceed 8.82 per cent. The calcareous sediments have a lower iron concentration and it decreases with increasing $\mathrm{CaCO}_{3}$. Values less than 1 per cent were found only in calcareous ooze, chalk, or limestone containing more than 75 per cent $\mathrm{CaCO}_{3}$. Concentrations higher than 5 per cent occur in some red marl or claystone layers in the variegated sediments of Sites 390 and 391. The iron content in the Lower Cretaceous black and gray claystone of Site 391 is rather low. At Site 388 it is quite uniform in the terrigenous clay and silty clay (3.79\% to $4.57 \%)$.

The iron content is less variable when calculated on a carbonate-free basis. It ranges from 1 per cent to 12.5 per cent. Moreover, the extreme values were obtained from the high-calcareous samples, where analytical errors are greater. The red and brown interbeds of the variegated sediments at Sites 390, 391, and the Tithonian red marl and calcareous claystone in Hole $391 \mathrm{C}$ are enriched in iron. The black claystone of Site 391 (unit 3) and the gray limestone of Site 391 (unit 4) yielded several high values. The lowest concentrations occurred in the intraclastic chalk of Site 391.

As determined by the phase analysis (Table 2), 3valent iron predominates over other forms in most samples. The concentration in bulk samples is 0.29 per cent to 5.46 per cent and the relative portion ranges from 12.6 per cent to 100 per cent of total iron. Insoluble $\mathrm{Fe}^{+3}$ comprises 76 per cent to 98 per cent of the total iron in the Tithonian red marl, whereas soluble $\mathrm{Fe}^{+3}$ (mostly amorphous hydroxide) is apparently absent. The soluble $\mathrm{Fe}^{+3}$ is significant in Pleistocene clay and silty clay of Hole $388 \mathrm{~A}$, as well as in the variegated sediments of Sites 390 and 391. The highest relative abundance $(42.8 \%$ of total $\mathrm{Fe}$ ) was found in a "rusty" claystone, which contains limonitic(?) nodules (Hole 391A, Core 21, Section 2, 88$89 \mathrm{~cm}$ ). The claystone was probably a surface layer deposited on top of the reduced black and gray Cretaceous sequence which has been exposed and oxidized during a long period of time (see Site 391 Report, this volume).

The percentage of reduced insoluble iron $\left(\mathrm{Fe}^{+2}\right.$ insoluble), including that of pyrite, is variable. It is higher in some Lower Cretaceous black claystone layers of sub-unit 3b and unit 4 (Hole 391C) where pyrite was detected on smear slides. It is also relatively abundant in terrigenous silty clay of Hole $388 \mathrm{~A}$. Soluble $\mathrm{Fe}^{+2}$ is virtually absent in all samples except those of Lower Cretaceous black and gray claystones, where it is present as siderite. Siderite crystals were found in smear slides and thin-sections of these layers. 
TABLE 1

Iron, Manganese, and Titanium Contents

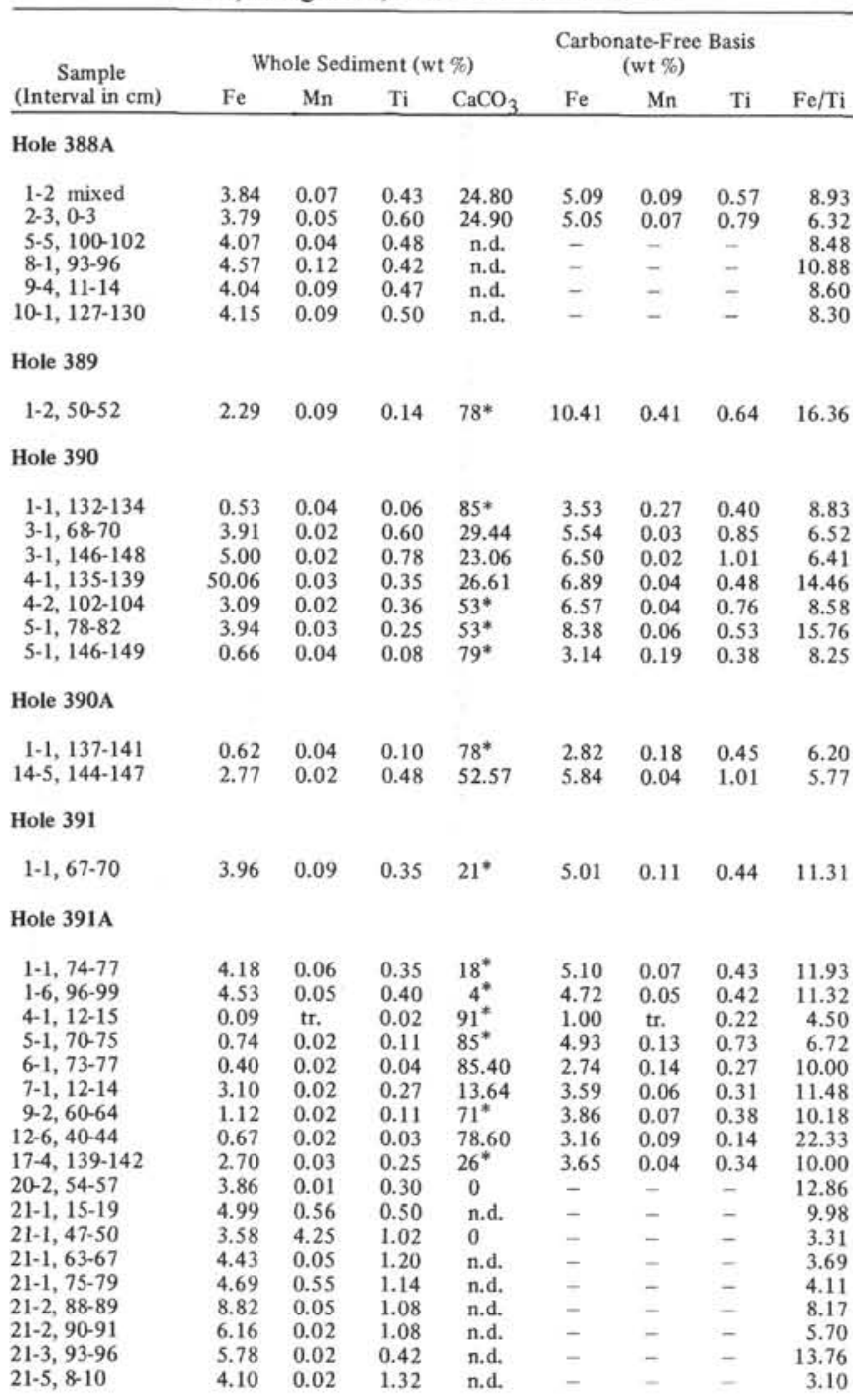

Hole 391C

\begin{tabular}{lrrrrrrrr}
$2-1,6-10$ & 0.98 & 0.02 & 0.11 & $73^{*}$ & 3.62 & 0.07 & 0.41 & 8.91 \\
$4-1,107-110$ & 4.90 & 0.01 & 0.45 & 0 & - & - & - & 10.89 \\
$5-1,72-75$ & 6.20 & 0.05 & 0.45 & 0 & - & - & - & 13.78 \\
$6-1,56-61$ & 5.69 & 0.02 & 0.40 & n.d. & - & - & - & 12.93 \\
$6-5,104-109$ & 4.99 & 0.02 & 0.46 & n.d. & - & - & - & 10.85 \\
$7-1,16-18$ & 4.95 & 0.03 & 00.50 & n.d. & - & - & - & 9.90 \\
$8-1,102-105$ & 4.70 & 0.02 & 0.38 & n.d. & - & - & - & 12.37 \\
$9-2,5-8$ & 16.53 & 0.66 & 0.48 & n.d. & - & - & - & 34.34 \\
$10-1,72-75$ & 4.43 & 0.02 & 10.06 & 0 & - & - & - & 4.10 \\
$10-2,108-111$ b & 6.50 & 0.04 & 1.20 & n.d. & - & - & - & 5.41 \\
$10-2,108-111 \mathrm{~g}$ & 3.99 & 0.02 & 1.32 & n.d. & - & - & - & 3.02 \\
$11-1,50-51$ & 3.00 & 0.15 & 0.17 & $59 *$ & 7.32 & 0.37 & 0.42 & 17.65 \\
$11-1,52-53$ & 3.77 & 0.03 & 0.32 & n.d. & - & - & - & 11.78 \\
$12-2,64-70$ & 1.76 & 0.02 & 0.08 & 75.22 & 7.10 & 0.08 & 0.32 & 22.00 \\
$12-6,93-96$ & 1.17 & 0.01 & 0.08 & 72.66 & 4.31 & 0.04 & 0.30 & 14.62 \\
$15-3,83-86$ & 3.75 & 0.02 & 0.34 & 18.01 & 4.57 & 0.02 & 0.41 & 11.03 \\
$17-2,36-38$ & 4.99 & 0.02 & 0.31 & 19.56 & 6.20 & 0.02 & 0.38 & 16.10 \\
$17-2,39-43$ & 1.30 & 0.02 & 0.13 & 54.98 & 2.95 & 0.04 & 0.29 & 10.23 \\
$17-2,74-77$ & 0.52 & 0.02 & 0.05 & 41.70 & 0.89 & 0.03 & 0.09 & 10.40 \\
$21-4,103-106$ & 4.54 & 0.02 & 0.31 & 25.56 & 6.10 & 0.03 & 0.42 & 14.64 \\
$24-1,115-117$ & 3.32 & 0.03 & 0.46 & 16.30 & 3.97 & 0.04 & 0.55 & 7.28 \\
$24-2,66-69$ & 0.47 & 0.02 & 0.01 & 92.55 & 6.31 & 0.27 & 0.13 & 47.00 \\
$24-6,35-38$ & 3.30 & 0.02 & 0.32 & n.d. & - & - & - & 10.31 \\
$25-2,62-65$ & 0.54 & 0.02 & 0.01 & 95.69 & 12.53 & 0.46 & 0.23 & 54.00 \\
$26-11,134-138$ & 0.62 & 0.02 & 0.04 & 93.92 & 10.33 & 0.33 & 0.66 & 15.50 \\
$26-2,63-65$ & 1.92 & 0.05 & 0.13 & $41 *$ & 3.25 & 0.08 & 0.22 & 14.77 \\
$26-3,56-58$ & 3.36 & 0.02 & 0.30 & 27.51 & 4.62 & 0.03 & 0.41 & 11.20 \\
$27-3,44-48$ & 0.51 & 0.02 & tr. & 94.82 & 9.85 & 0.39 & - & - \\
$28-2,106-110$ & 4.31 & 0.02 & 0.35 & 18.42 & 5.28 & 0.02 & 0.43 & 12.31 \\
$29-4$, & 3.16 & tr. & 0.23 & 39.16 & 5.19 & - & 0.38 & 13.74 \\
$29-4,146-150$ & 0.85 & 0.02 & 0.03 & 90.32 & 8.78 & 0.21 & 0.31 & 28.33 \\
$30-2,56-60$ & 0.64 & 0.02 & 0.02 & 85.96 & 4.56 & 0.14 & 0.14 & 32.00 \\
$30-4,43-46$ & 3.84 & 0.01 & 0.32 & 24.33 & 5.02 & 0.01 & 0.42 & 12.00 \\
\hline & & & & & & & &
\end{tabular}

TABLE 1 - Continued

\begin{tabular}{|c|c|c|c|c|c|c|c|c|}
\hline \multirow{2}{*}{$\begin{array}{c}\text { Sample } \\
\text { (Interval in } \mathrm{cm} \text { ) }\end{array}$} & \multicolumn{4}{|c|}{ Whole Sediment (wt \%) } & \multicolumn{3}{|c|}{$\begin{array}{l}\text { Carbonate-Free Basis } \\
\text { (wt \%) }\end{array}$} & \multirow[b]{2}{*}{$\mathrm{Fe} / \mathrm{Ti}$} \\
\hline & $\mathrm{Fe}$ & $\mathrm{Mn}$ & $\mathrm{Ti}$ & $\mathrm{CaCO}_{3}$ & $\mathrm{Fe}$ & $\mathrm{Mn}$ & $\mathrm{Ti}$ & \\
\hline \multicolumn{9}{|c|}{ Hole 391C Continued } \\
\hline $31-5,78-81$ & 5.06 & 0.01 & 0.45 & 10.92 & 5.68 & 0.01 & 0.50 & 11.24 \\
\hline $31-6,133-137$ & 1.10 & 0.03 & 0.07 & 85.96 & 7.84 & 0.21 & 0.50 & 15.71 \\
\hline $32-4,91-93$ & 1.39 & 0.02 & 0.13 & 74.18 & 5.52 & 0.08 & 0.50 & 10.69 \\
\hline $33-3,82-86$ & 0.56 & 0.08 & 0.03 & 85.87 & 3.96 & 0.57 & 0.21 & 18.67 \\
\hline $34-1,127-131$ & 2.30 & 0.04 & 0.17 & 46.84 & 4.33 & 0.08 & 0.32 & 13.53 \\
\hline $34-4,20-22$ & 1.50 & 0.13 & 0.11 & 75.72 & 6.18 & 0.54 & 0.45 & 13.64 \\
\hline $36-3,9-12$ & 1.72 & 0.08 & 0.11 & 71.49 & 6.05 & 0.26 & 0.39 & 15.64 \\
\hline $36-4,86-87$ & 2.72 & 0.06 & 0.15 & 62.99 & 7.35 & 0.16 & 0.40 & 18.13 \\
\hline $38-1,127-131$ & 0.54 & 0.06 & 0.02 & 90.14 & 5.48 & 0.61 & 0.21 & 27.00 \\
\hline $39-5,141-145$ & 0.95 & 0.05 & 0.04 & 84.25 & 6.02 & 0.32 & 0.25 & 43.75 \\
\hline $40-2,125-131$ & 0.92 & 0.06 & 0.05 & 84.59 & 5.97 & 0.39 & 0.32 & 18.40 \\
\hline $42-4,116-120$ & 0.67 & 0.04 & 0.02 & 84.14 & 4.22 & 0.25 & 0.13 & 33.50 \\
\hline $44-2,125-128$ & 2.93 & 0.01 & 0.23 & 40.39 & 4.92 & 0.02 & 0.39 & 12.74 \\
\hline $44-6,84-85$ & 0.76 & 0.06 & 0.02 & 92.10 & 9.62 & 0.76 & 0.25 & 38.00 \\
\hline $45-3,35-36$ & 1.78 & 0.05 & 0.13 & 62.36 & 4.73 & 0.65 & 0.34 & 13.69 \\
\hline $45-3,71-77$ & 0.56 & 0.05 & tr. & 81.04 & 1.93 & 0.18 & - & - \\
\hline $46-1,139-142$ & 4.90 & 0.05 & 0.30 & 25.04 & 6.54 & 0.07 & 0.40 & 16.33 \\
\hline $47-1,41-43$ & 2.24 & 0.11 & 0.16 & 58.89 & 5.45 & 0.27 & 0.39 & 14.00 \\
\hline $47-1,98-99$ & 4.38 & 0.07 & 0.28 & 24.88 & 5.83 & 0.01 & 0.37 & 15.64 \\
\hline $47-1,99-100$ & 2.10 & 0.11 & 0.14 & 56.40 & 4.82 & 0.25 & 0.32 & 15.00 \\
\hline $48-1,135-137$ & 0.98 & 0.25 & 0.02 & 88.23 & 8.33 & 2.12 & 0.17 & 49.00 \\
\hline $49-2,81-83$ & 4.40 & 0.06 & 0.26 & 28.88 & 6.19 & 0.06 & 0.36 & 16.92 \\
\hline $49-2,137-139 b$ & 5.04 & 0.02 & 0.36 & 18.93 & 6.21 & 0.02 & 0.44 & 13.19 \\
\hline $49-2,137-139 \mathrm{bl}$ & 5.54 & 0.02 & 0.42 & 8.60 & 6.06 & 0.02 & 0.46 & 14.00 \\
\hline $50-1,78-80$ & 2.20 & 0.79 & 0.14 & 68.67 & 7.02 & 2.52 & 0.45 & 15.71 \\
\hline $50-1,118-120$ & 3.25 & 0.15 & 0.42 & 42.83 & 5.68 & 0.26 & 0.74 & 15.54 \\
\hline $52-2,103-106$ & 3.92 & 0.02 & 0.36 & 18.27 & 4.80 & 0.02 & 0.44 & 10.89 \\
\hline $52-4,13-15$ & 5.90 & 0.05 & 0.30 & 23.88 & 7.15 & 0.07 & 0.39 & 16.67 \\
\hline $52-4,40-42$ & 4.90 & 0.03 & 0.40 & 13.87 & 5.69 & 0.03 & 0.46 & 12.25 \\
\hline
\end{tabular}

Note: ${ }^{*}=\mathrm{CaCO}_{3}$ content in the sample was not determined; the closest carbonate bomb or carbon carbonate determination was used for the carbonate-free

The highest percentage of the soluble bivalent iron ( $14.45 \%$ of bulk sample of $87.4 \%$ of total iron) was found in a sideritic interbed of Hole 391C, Core 9, Section 2, 5-8 cm.

Manganese: The manganese content (Table 1) is low (less than $0.1 \%$ ) throughout except for a few samples from the variegated sediments, where it is 0.79 per cent, and in one case to 4.25 per cent. The latter is represented mostly by $\mathrm{MnO}_{2}$. Only $\mathrm{MnO}$ was detected in the other samples which were subjected to phase analysis.

The manganese content is also low when calculated on a carbonate-free basis, although in some cases it is higher than 0.2 per cent in gray limestone of unit 4 and red marl of unit 5 (Site 391).

Titanium: The titanium content (Table 1, Figure 1) ranges from 0.01 per cent to 1.32 per cent. It is lowest in calcareous sediments where titanium-bearing clastic minerals are diluted by biogenic $\mathrm{CaCO}_{3}$. Values higher than 0.5 per cent were found only in Cretaceous variegated claystones of Site 391. When calculated on the carbonate-free basis, the concentration of titanium is virtually uniform. Values of 0.3 per cent to 0.5 per cent titanium are common in all types of sediment except in the variegated claystone which contain more titanium. Samples high in calcium carbonate, where analytical errors are possibly larger, produced values lower than 0.3 per cent on a carbonate-free basis.

Aluminum: The aluminum content, determined only in 26 samples (Table 2), ranges from 0.9 per cent to 11.5 per cent. The calcareous sediments gave low values which disappear altogether when the aluminum content is calculated on a carbonate-free basis. No real lowaluminum sediments, comparable with those of the Mid-Pacific Rise (Boström et al., 1969) were found at the Leg 44 sites. On the contrary, the variegated 


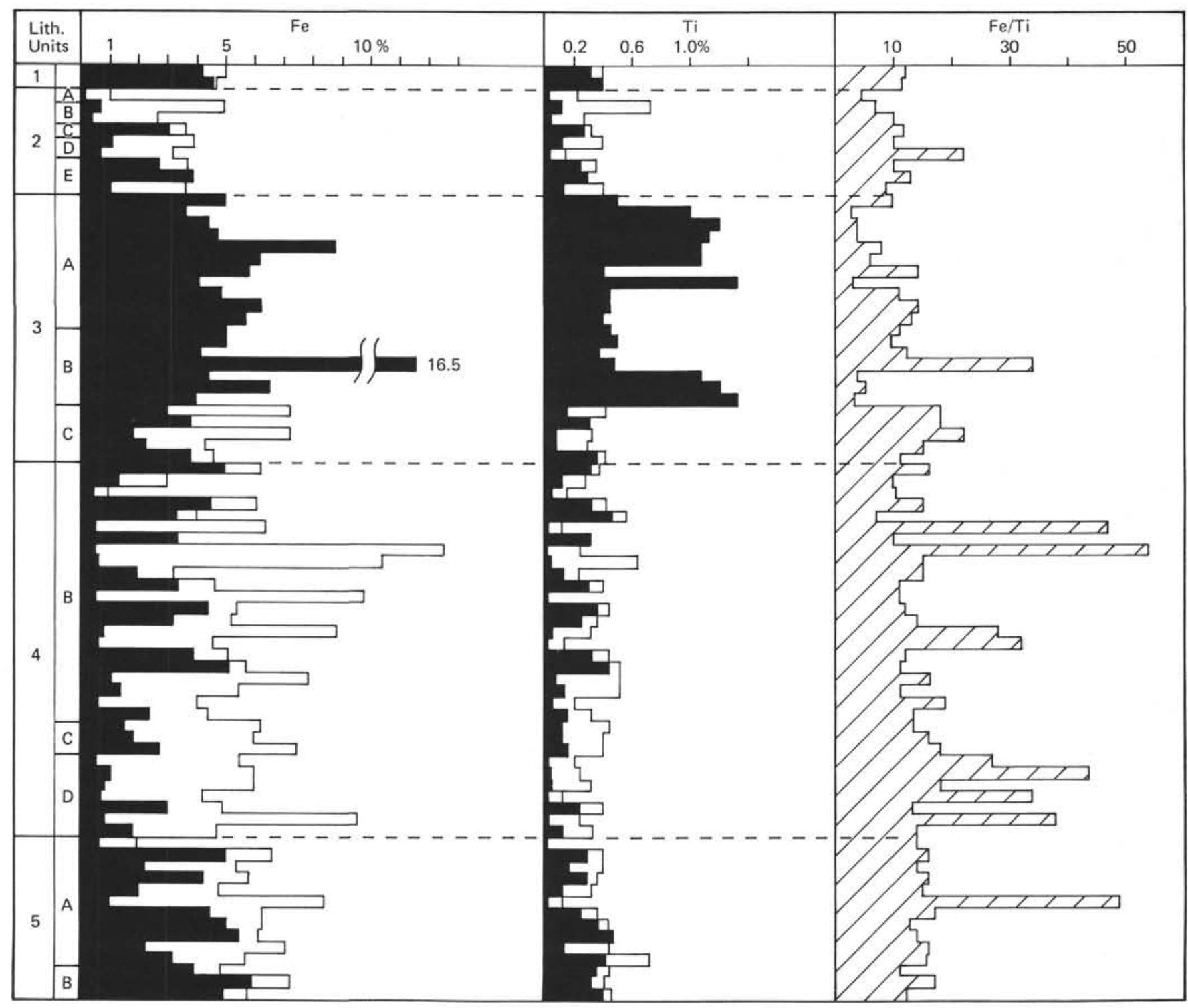

$=\%$ of the element in natural dry sample
$=\%$ calculated on carbonate-free base

Figure 1. Iron and titanium in the Site 391 sediments.

claystones at Site 391 are somewhat enriched in aluminum compared with "normal" pelagic red clays. Only a weak decreasing trend is noted in the Tithonian red marls.

Relationships between total $\mathrm{Fe}$ to $\mathrm{Al}$ and $\mathrm{Ti}$ are expressed as ratios $(\mathrm{Fe} / \mathrm{Al}$ and $\mathrm{Fe} / \mathrm{Ti}$ and $(\mathrm{Fe}+\mathrm{Mn}) / \mathrm{Ti},(\mathrm{Fe}+\mathrm{Mn}) / \mathrm{Al}$, and others) in order to determine what portion of iron in the sediments exceeds that of "normal" terrigenous clay (Boström et al., 1969; Strakhov, 1976). The ratios do not vary greatly in common hemipelagic and pelagic sediments, but because exhalative iron has been added to the normal terrigenous sediments the value ncreases considerably in active-ridge "metalliferous" sediments. Exhalative matter is very low in both aluminum and titanium (Boström et al., 1969), and thus tends to raise the value of the ratio. The presence of basaltic volcaniclastic matter containing more titanium and less aluminum than terrigenous clay considerably lowers the $\mathrm{Fe} / \mathrm{Ti}$ ratio and raises the $\mathrm{Fe} / \mathrm{Al}$ ratio. Consequently, these ratios become less informative when applied to sediments containing exhalative matter. The $\mathrm{Al} / \mathrm{Ti}$ ratio of the basaltic volcaniclastic matter is distinctly lower than that of terrigenous clay. The difference is commonly preserved during alteration of volcaniclastic matter to clay, because of low mobility of both elements during diagenesis. Thus, the ratio may be applied to distinguish land-derived clay from that formed from basaltic volcaniclastic rock.

The Leg 44 samples, analyzed for aluminum, fall into two groups on the basis of their $\mathrm{Al} / \mathrm{Ti}$ ratio. Group 1 comprises samples with "normal" terrigenous values (15-20) or somewhat higher. (i.e., enriched in $\mathrm{Al}$ versus Ti) and includes the Miocene intraclastic chalk and 
TABLE 2

Iron Phase-Analysis Data on Selected Samples of the Leg 44 Sediments

\begin{tabular}{|c|c|c|c|c|c|c|c|c|c|}
\hline \multirow[b]{2}{*}{$\begin{array}{c}\text { Sample } \\
\text { (Interval in } \mathrm{cm} \text { ) }\end{array}$} & \multirow[b]{2}{*}{$\begin{array}{c}\mathrm{Fe} \\
\text { Total }\end{array}$} & \multicolumn{2}{|c|}{$\mathrm{Fe}^{3}$ Insol. } & \multicolumn{2}{|c|}{$\mathrm{Fe}^{+3}$ Sol. } & \multirow{2}{*}{$\mathrm{Fe}^{+2}$} & \multirow{2}{*}{$\begin{array}{l}\text { Insol. } \\
\% \text { of } \\
\text { Total }\end{array}$} & \multicolumn{2}{|c|}{$\mathrm{Fe}^{+2}$ Sol. } \\
\hline & & $\%$ & $\begin{array}{l}\% \text { of } \\
\text { Total }\end{array}$ & $\%$ & $\begin{array}{l}\% \text { of } \\
\text { Total }\end{array}$ & & & & $\begin{array}{l}\% \text { of } \\
\text { Total }\end{array}$ \\
\hline $388 \mathrm{~A}-2-3,0-3$ & 3.79 & 2.38 & 61.7 & 0.94 & 24.4 & 0.54 & 14.0 & 0 & 0 \\
\hline $388 \mathrm{~A}-2-3,147-150$ & 4.43 & 2.92 & 6.58 & 0.42 & 9.5 & 1.10 & 24.8 & 0 & 0 \\
\hline $390-3-1,68-70$ & 3.91 & 2.93 & 75.1 & 0.78 & 20.0 & 0.19 & 4.9 & 0 & 0 \\
\hline $390-3-1,146-148$ & 5.00 & 4.10 & 82.0 & 0.63 & 12.6 & 0.27 & 5.4 & 0 & 0 \\
\hline $390 \mathrm{~A}-14-5,144-147$ & 2.77 & 1.96 & 70.8 & 0.62 & 22.4 & 0.19 & 6.9 & 0 & 0 \\
\hline $391 \mathrm{~A}-21-1,47-50$ & 3.58 & 3.58 & 100 & 0 & 0 & 0 & 0 & 0 & 0 \\
\hline $391 \mathrm{~A}-21-1,63-67$ & 4.43 & 3.74 & 84.2 & 0.43 & 9.7 & 0.27 & 6.1 & 0 & 0 \\
\hline $391 \mathrm{~A}-21-1,75-79$ & 4.69 & 4.57 & 97.2 & 0 & 0 & 0.13 & 2.8 & 0 & 0 \\
\hline $391 \mathrm{~A}-21-2,88-89$ & 8.82 & 4.92 & 55.8 & 3.78 & 42.8 & 0.12 & 1.4 & 0 & 0 \\
\hline $391 \mathrm{~A}-21-2,90-91$ & 6.16 & 5.34 & 86.7 & 0.38 & 6.2 & 0.12 & 2.0 & 0 & 0 \\
\hline $391 \mathrm{~A}-21-3,8-10$ & 4.10 & 3.79 & 92.2 & 0 & 0 & 0.32 & 7.8 & 0 & 0 \\
\hline $391 C-6-5,104-109$ & 4.99 & 3.12 & 62.5 & 0 & 0 & 0.07 & 1.4 & 1.60 & \\
\hline $391 C-7-1,16-18$ & 4.95 & 3.04 & 61.4 & 0 & 0 & 0.07 & 1.4 & 1.84 & 37 \\
\hline $391 C-8-1,102-105$ & 4.70 & 1.59 & 33.8 & 0 & 0 & 0.33 & 7.0 & 2.78 & 59 \\
\hline $391 C-9-2,5-8$ & 16.53 & 2.09 & 12.6 & 0 & 0 & 0 & 0 & 14.45 & 87 \\
\hline $391 \mathrm{C}-10-1,72-74$ & 4.43 & 2.93 & 66.1 & 0 & 0 & 0.81 & 18.3 & 0.62 & 16 \\
\hline $391 \mathrm{C}-10-2,108-111 \mathrm{~b}$ & 6.50 & 5.46 & 84.0 & 0.77 & 12 & 0.27 & 4.2 & 0 & 0 \\
\hline $391 \mathrm{C}-10-2,108-111 \mathrm{~g}$ & 3.99 & 3.87 & 96.8 & 0 & 0 & 0.13 & 3.2 & 0 & 0 \\
\hline $391 \mathrm{C}-24-1,115-117$ & 3.32 & 1.38 & 41.6 & 0 & 0 & 0.61 & 18.4 & 1.33 & 40 \\
\hline $391 \mathrm{C}-24-6,35-38$ & 3.30 & 1.37 & 41.5 & 0 & 0 & 0.83 & 25.2 & 1.10 & 33 \\
\hline $391 C-26-2,63-65$ & 1.92 & 0.49 & 25.2 & 0 & 0 & 0.55 & 28.6 & 0.88 & 46 \\
\hline $391 C-45-3,71-77$ & 0.56 & 0.29 & 51.8 & 0 & 0 & 0.27 & 48.2 & 0 & 0 \\
\hline $391 C-46-1,139-142$ & 4.90 & 4.69 & 95.7 & 0 & 0 & 0.28 & 4.3 & 0 & 0 \\
\hline $391 C-47-1,41-43$ & 2.24 & 1.70 & 75.9 & 0 & 0 & 0.54 & 24.1 & 0 & 0 \\
\hline $391 C-49-2,137-139 b 1$ & 5.54 & 4.57 & 82.5 & 0 & 0 & 0.27 & 4.9 & 0 & 0 \\
\hline $391 C-49-2,137-139 b$ & 5.04 & 4.92 & 97.6 & 0 & 0 & 0.12 & 2.4 & 0 & 0 \\
\hline $381 C-50-1,118-120$ & 3.25 & 2.85 & 87.7 & 0 & 0 & 0,40 & 12.4 & 0 & 0 \\
\hline $391 C-52-2,103-106$ & 3.92 & 3.24 & 82.6 & 0 & 0 & 0.68 & 17.4 & 0 & 0 \\
\hline
\end{tabular}

Note: $\mathrm{Fe}$ of pyrite included in $\mathrm{Fe}^{+2}$ unsol. $\mathrm{b}=$ brown layer; $\mathrm{g}=$ gray layer; $\mathrm{bl}=$ black layer.

turbidites, Lower Cretaceous black and gray claystones, and Upper Jurassic red marl. Group 2 comprises samples with low $\mathrm{Al} / \mathrm{Ti}$ ratios (7.1-10.2) and includes the Cretaceous red and variegated claystones above the black and gray sequence. Admixture of basaltic (high-titanium) matter is possibly responsible for the low $\mathrm{Al} / \mathrm{Ti}$ ratio.

Except for a sideritic interbed where it is 4.35 , the $\mathrm{Fe} / \mathrm{Al}$ ratios in the Leg 44 samples are rather low and range from 0.38 to 1.07 (Table 3). No definite pattern can be inferred from these data. Note, however, that the ratio in the variegated claystone intervals at Sites 390 and 391, as well as in the Upper Jurassic red marl (Hole 391C, unit 5), does not increase significantly. Instead it is lower in several samples from these layers which indicates a relative enrichment in aluminum versus iron.

The Fe/Ti ratio (Table 1, Figure 1) is highly variable. It ranges from very low (3-4) to very high (54) values. Most of the values higher than 20 occur in calcareous samples which contain very little iron and titanium. Our experimental accuracy in these cases is not high enough to allow great confidence in the data. Nonetheless, the values are highest in gray to bluish white limestone of Site 391, unit 4 . The limestone contains pyrite, relatively large amounts of organic carbon, and very small amounts of clastic material. The presence of diagenetic iron minerals, such as pyrite and siderite, probably causes the relative enrichment in iron. The $\mathrm{Fe} / \mathrm{Ti}$ ratio is relatively high (11 to 17$)$ in the Tithonian red marl and calcareous claystone. It is low
( 3 to 13 ) in variegated claystone of sub-unit $3 a$, Site 391 , and in the variegated marly nannofossil ooze of unit 7 , Site 390.

Copper: We determined the copper content in 46 samples (Table 4). It ranges from 6 to $240 \mathrm{ppm}$ ( 23 to $254 \mathrm{ppm}$ on a carbonate-free basis). These values fall within the limits established for common Recent deepsea sediments and are much lower than those in metalliferous sediments (Boström and Peterson, 1969; Lisitzyn et al., 1976). Even the maximum concentrations in our samples are not as high as averages in Recent Pacific pelagic sediments (281 ppm, Skornyakova, 1976). Some blackclay samples and the foraminiferal sand on the Blake Nose (Site 389) have relatively large amounts of copper (carbonate-free basis). The variegated sediments and the Tithonian red marl are low in copper.

Zinc: Zinc in deep-sea sediments has not been widely studied. Bischoff (1969) detected very high zinc contents in the Red Sea metalliferous sediments. The average concentration in the East Pacific Rise metalliferous sediments is about 290 to $380 \mathrm{ppm}$ (Lisitzyn et al., 1976). This is not much higher than that found in Pacific pelagic sediments $(166 \mathrm{ppm}$, Skornyakova, 1976). Zinc concentrations of $43 \mathrm{ppm}$ to $292 \mathrm{ppm}$ was detected in the multi-colored clay at Site 105 (Leg 11, western North Atlantic, Lancelot et al., Hathaway and Hollister, 1972).

In the Leg 44 sediments zinc ranges from $10 \mathrm{ppm}$ to $146 \mathrm{ppm}$ or $26 \mathrm{ppm}$ to $254 \mathrm{ppm}$, when calculated on a carbonate-free basis (Table 4). We obtained several 
TABLE 3

Aluminum Content and Characteristic Ratios with Aluminum in the Leg 44 Sediments

\begin{tabular}{|c|c|c|c|c|}
\hline $\begin{array}{c}\text { Sample } \\
\text { (Interval in } \mathrm{cm} \text { ) }\end{array}$ & $\begin{array}{c}\mathrm{Al} \\
\text { wt. } \%\end{array}$ & $\mathrm{Fe} / \mathrm{Al}$ & $\begin{array}{c}\mathrm{Fe}+\mathrm{Mn} \\
\mathrm{Al}\end{array}$ & $\mathrm{Al} / \mathrm{Ti}$ \\
\hline $388 \mathrm{~A}-2-3,0-3$ & 6.5 & 0.58 & 0.59 & 10.8 \\
\hline $390-3-1,146-148$ & 8.4 & 0.60 & 0.60 & 14.0 \\
\hline $390 \mathrm{~A}-14-5,144-147$ & 4.0 & 0.69 & 0.70 & 8.3 \\
\hline $391 \mathrm{~A}-17-4,139-142$ & 4.9 & 0.55 & 0.56 & 19.6 \\
\hline $391 \mathrm{~A}-20-2,54-57$ & 6.7 & 0.58 & 0.58 & 22.3 \\
\hline $391 \mathrm{~A}-21-1,47-50$ & 9.3 & 0.38 & 0.84 & 8.6 \\
\hline $391 \mathrm{~A}-21-1,63-67$ & 10.3 & 0.43 & 0.43 & 8.6 \\
\hline $391 \mathrm{~A}-21-1,75-79$ & 11.5 & 0.41 & 0.48 & 10.1 \\
\hline $391 \mathrm{~A}-21-1,88-89$ & 10.1 & 0.86 & 0.87 & 9.4 \\
\hline $391 \mathrm{~A}-21-2,90-91$ & 11.0 & 0.56 & 0.56 & 10.2 \\
\hline $391 \mathrm{~A}-21-3,93-96$ & 8.7 & 0.66 & 0.67 & 20.7 \\
\hline $391 \mathrm{~A}-21-5,8-10$ & 10.2 & 0.40 & 0.40 & 7.8 \\
\hline $391 \mathrm{C}-2-1,6-10$ & 2.1 & 0.47 & 0.48 & 19.1 \\
\hline $391 C-4-1,107-110$ & 9.5 & 0.52 & 0.52 & 21.1 \\
\hline $391 C-5-1,72-75$ & 9.1 & 0.68 & 0.69 & 20.2 \\
\hline $391 C-6-1,56-61$ & 9.1 & 0.62 & 0.63 & 22.8 \\
\hline $391 C-6-5,104-109$ & 10.5 & 0.47 & 0.48 & 22.8 \\
\hline $391 C-7-1,16-18$ & 10.3 & 0.48 & 0.48 & 21.0 \\
\hline $391 C-8-1,102-105$ & 10.1 & 0.46 & 0.47 & 26.6 \\
\hline $391 C-2,5-8$ & 3.8 & 4.35 & 4.52 & 7.9 \\
\hline $391 C-10-1,72-74$ & 10.0 & 0.44 & 0.44 & 9.4 \\
\hline $391 \mathrm{C}-10-2,108-111 \mathrm{~b}$ & 10.0 & 0.65 & 0.65 & 8. \\
\hline $391 \mathrm{C}-10-2,108-111 \mathrm{~g}$ & 9.4 & 0.42 & 0.43 & 7.1 \\
\hline $391 C-15-3,83-86$ & 6.2 & 0.60 & 0.61 & 18.2 \\
\hline $391 C-24-1,115-117$ & 7.6 & 0.44 & 0.44 & 16.5 \\
\hline $391 C-24-6,35-38$ & 5.1 & 0.65 & 0.65 & 15.9 \\
\hline $391 C-26-2,63-65$ & 2.6 & 0.74 & 0.76 & 20.0 \\
\hline $391 \mathrm{C}-28-2,106-110$ & 6.1 & 0.71 & 0.71 & 19.7 \\
\hline $391 C-45-3,71-77$ & 0.9 & 0.62 & 0.68 & - \\
\hline $391 C-46-1,139-142$ & 6.6 & 0.74 & 0.75 & 22.0 \\
\hline $391 C-47-1,41-43$ & 3.7 & 0.50 & 0.63 & 23. \\
\hline $391 C-49-2,81-83$ & 4.7 & 0.94 & 0.94 & 18. \\
\hline $391 \mathrm{C}-49-2,137-139 \mathrm{bl}$ & 8.0 & 0.69 & 0.70 & 22. \\
\hline $391 C-49-2,137-139 b$ & 7.6 & 0.66 & 0.66 & 18. \\
\hline $391 C-50-1,118-120$ & 5.0 & 0.65 & 0.68 & 11.9 \\
\hline $391 C-52-2,103-106$ & 6.8 & 0.58 & 0.58 & 29.6 \\
\hline $391 C-52-4,13-15$ & 5.5 & 1.07 & 1.08 & 18.3 \\
\hline
\end{tabular}

Note: $\mathrm{b}=$ brown layer; $\mathrm{g}=$ gray layer $; \mathrm{bl}=$ black layer.

higher values from the black or gray interbeds within, or directly below the Cretaceous variegated intervals (Hole 391A, Core 21; Hole 391C, Core 10). We discovered analytical errors, however, which forced us to exclude the numbers from Table 4 . Nevertheless, the layers seem to be relatively enriched in zinc. The sediments with an increased zinc content (140 ppm-146 ppm) occur in Hole 391C, Cores 6 to 8 (upper part of the Cretaceous black and gray claystone sequence). Lancelot et al. (1972) found authigenic sphalerite and high zinc contents in the similar Upper Cretaceous layers at Site 105 (Leg 11). The Lower Cretaceous and Upper Jurassic calcareous rocks are low in zinc content.

Nickel: Nickel is a typical metal in oceanic manganese nodules and red clays, where it is closely associated with manganese. In hemipelagic sediments the nickel content (as well as manganese) is low. The average $221 \mathrm{ppm}$, for example, was obtained from Recent Pacific pelagic sediments, whereas in hemipelagic mud the average is $82 \mathrm{ppm}$ (Skornyakova, 1976, table 26). A sharp increase in nickel shows the presence of active ridge metalliferous sediments (Boström et al., 1969).
The data in Table 4 show rather low nickel values (less than $100 \mathrm{ppm}$ ) in most of the examined sediments. A rather weak increase occurs in the upper portion of the Cretaceous black and gray claystones sequence (Hole 391C, Cores 6 to 9). The Miocene intraclastic chalk (Site 391) contains $58 \mathrm{ppm}$ to $261 \mathrm{ppm}$ of nickel (carbonate-free basis). Calcareous ooze and chalk on the Blake Nose (Sites 389,390 ) varies from $63 \mathrm{ppm}$ to $614 \mathrm{ppm}$. The single highest value was obtained from a manganese nodule-bearing foraminifer ooze from the sea-floor surface. The Upper Jurassic red marl is somewhat enriched in carbonate-free nickel; the values (116-212 ppm), however, are lower than averages in pelagic sediments.

Cobalt: We have analyzed only a few samples from the Hole 391C Cretaceous and Upper Jurassic sections for cobalt (Table 4). All values are low. They are comparable with those for hemipelagic sediments but are much lower than averages for pelagic sediments.

Chromium: Chromium is known to be associated mostly with clastic minerals and with clay derived from altered basalts. The average values in terrigenous and pelagic sediments range commonly between $60 \mathrm{ppm}$ and $110 \mathrm{ppm}$. Most of our data (Table 4) fall within these limits, although several higher values $(130 \mathrm{ppm}$ to $200 \mathrm{ppm}$ ) occur occasionally on carbonate-free basis in the variegated marly nannofossil ooze at Site 390 , the Miocene intraclastic chalk, and other layers at Site 391.

Bulk Composition: Bulk composition of several selected samples from Site 391 was determined by Xray fluorescence (Table 5). The lithologies of the samples is as follows:

1) Miocene intraclastic chalk (Sample 391C-2-1, 6$10 \mathrm{~cm}$ ); calcareous claystone (Sample 391A-17-4, 6-10 $\mathrm{cm}$ ), and claystone with glauconite (Sample 391A-20-2, $54-57 \mathrm{~cm}$ ).

2) Upper Cretaceous variegated claystones (samples from Hole 391A, Core 21 and Hole 391C, Cores 4 to 6).

3) Upper Cretaceous to Albian black and olive-gray claystones (Samples 391C-10-15, 72-75 cm and 391C$10-2,108-111 \mathrm{~cm}$ ).

4) Calcareous claystone and marly limestone interbeds in the Lower Cretaceous limestone sequence (Samples 391C-15-3, 83-86 cm and 391C-28-2, 106-110 $\mathrm{cm})$.

5) Upper Jurassic red marly limestone (Samples $391 \mathrm{C}-49-2,81-83 \mathrm{~cm}$ and $391 \mathrm{C}-52-4,13-15 \mathrm{~cm})$.

The data show that the Miocene massive gravity flow deposits, both chalk and claystone, are enriched by $\mathrm{SiO}_{2}$ relative to $\mathrm{Al}_{2} \mathrm{O}_{3}$. The $\mathrm{SiO}_{2} / \mathrm{Al}_{2} \mathrm{O}_{3}$ ratio is 4.5 to 5.0 , which indicates that more $\mathrm{SiO}_{2}$ is found than is usually present in hemipelagic claystone. The presence of siliceous microfossils is probably responsible for the enrichment. The $\mathrm{MgO}$ content in the sediments is rather high and that of $\mathrm{K}_{2} \mathrm{O}$ is low. This is in accordance with the clay mineral composition (domination of montmorillonite).

The variegated claystones in contrast are relatively low in $\mathrm{SiO}_{2}$ (49.3\% to 55.8\%) and high in $\mathrm{Al}_{2} \mathrm{O}_{3}$. The $\mathrm{SiO}_{2} / \mathrm{Al}_{2} \mathrm{O}_{3}$ ratio is between 2.8 to 3.3 . This, as well as the lower $\mathrm{MgO}$ and higher $\mathrm{K}_{2} \mathrm{O}$, may be attributed to the mineralitic composition of the clay. Kaolinite and mixed-layer illite-montmorillonite were detected in these layers (Pastouret et al., this volume). 
TABLE 4

Trace Elements in the Leg 44 Sediments (ppm)

\begin{tabular}{|c|c|c|c|c|c|c|c|c|c|c|}
\hline \multirow{2}{*}{$\begin{array}{c}\text { Sample } \\
\text { (Interval in } \mathrm{cm} \text { ) }\end{array}$} & \multicolumn{5}{|c|}{ Natural Sediment } & \multicolumn{5}{|c|}{$\mathrm{CaCO}_{3}$-Free Basis } \\
\hline & $\mathrm{Cu}$ & $\mathrm{Zn}$ & $\mathrm{Ni}$ & Co & $\mathrm{Cr}$ & $\mathrm{Cu}$ & $\mathrm{Zn}$ & $\mathrm{Ni}$ & Co & $\mathrm{Cr}$ \\
\hline 388A-1-2, mixed & 29 & 79 & 40 & - & 86 & 38 & 105 & 53 & - & 114 \\
\hline $388 \mathrm{~A}-2-3,0-3$ & 33 & 70 & 40 & - & & 46 & 95 & 54 & - & 100 \\
\hline $388 \mathrm{~A}-2-3,147-150$ & 46 & 78 & 56 & - & 86 & - & - & - & - & - \\
\hline $388 \mathrm{~A}-5-5,100-102$ & 61 & 104 & 63 & - & 85 & - & - & - & & - \\
\hline $388 \mathrm{~A}-8-1,93-96$ & 48 & 110 & 62 & - & 84 & - & - & - & - & - \\
\hline $388 \mathrm{~A}-9-4,11-14$ & 50 & 104 & 67 & - & 100 & - & - & - & - & - \\
\hline $388 \mathrm{~A}-10-1,127-130$ & 58 & 109 & 61 & - & 74 & - & - & - & - & - \\
\hline $389-1-2,50-52$ & 56 & 57 & 135 & - & 24 & 254 & 254 & 614 & - & 109 \\
\hline $390-1-1,132-134$ & 18 & 21 & 21 & - & 14 & 120 & 140 & 140 & - & 93 \\
\hline $390-3-1,68-70$ & 31 & 115 & 50 & - & 74 & 41 & 153 & 66 & - & 100 \\
\hline $390-3-1,146-148$ & 25 & 100 & 82 & - & 100 & 33 & 130 & 107 & - & 130 \\
\hline $390-4-1,135-139$ & 36 & 91 & 46 & - & 78 & 49 & 124 & 63 & - & 106 \\
\hline $390-4-2,102-104$ & 36 & 111 & 97 & - & 8 & 76 & 236 & 206 & - & 172 \\
\hline $390-5-1,78-82$ & 31 & 78 & 54 & - & 6 & 66 & 116 & 115 & - & 140 \\
\hline $390-5-1,146-148$ & 15 & 33 & 17 & - & 24 & 71 & 157 & 81 & - & 114 \\
\hline $390 \mathrm{~A}-1-1,137-141$ & 15 & 34 & 30 & - & 20 & 68 & 154 & 136 & - & 91 \\
\hline $390 \mathrm{~A}-1$ & 20 & 72 & 72 & 20 & 44 & 42 & 153 & 156 & 44 & 93 \\
\hline $391-1-1,67$ & 34 & 94 & 46 & - & 8 & 43 & 119 & 58 & - & 101 \\
\hline $391 \mathrm{~A}-1-1,74-77$ & 66 & 106 & 63 & - & 9 & 80 & 129 & 77 & - & 110 \\
\hline $391 \mathrm{~A}-1-6,96-99$ & 74 & 96 & 56 & - & 74 & 77 & 100 & 58 & - & 77 \\
\hline 391 & 6 & 1 & 10 & - & 16 & 67 & & 111 & - & 78 \\
\hline & 19 & 2 & 20 & - & 30 & 127 & 187 & & - & 200 \\
\hline $391 \mathrm{~A}-6-1,73-77$ & 16 & 24 & 41 & - & 23 & 109 & 164 & 261 & - & 157 \\
\hline $91 \mathrm{~A}-21-1,47-50$ & 193 & - & - & - & - & - & - & - & - & - \\
\hline 11 & 63 & - & - & - & - & - & - & - & - & - \\
\hline 3 & & - & - & - & - & - & - & - & - & - \\
\hline & 103 & - & - & - & - & - & - & - & - & - \\
\hline $91 \mathrm{~A}-21-2,90-91$ & 2 & - & - & - & - & - & - & - & - & - \\
\hline $91 \mathrm{~A}-21-55,8-10$ & 45 & - & - & - & - & - & - & - & - & - \\
\hline $4-109$ & 240 & 146 & 126 & 25 & 90 & - & - & - & - & - \\
\hline $6-18$ & 146 & 140 & 84 & 22 & 72 & - & - & - & - & - \\
\hline $02-105$ & 8 & 146 & 105 & 13 & 80 & - & - & - & - & - \\
\hline $391 C-9-2,5-8$ & 28 & 85 & 120 & 36 & 42 & - & - & - & - & - \\
\hline $391 \mathrm{C}-10-1,72-75$ & 235 & - & - & - & - & - & - & - & - & - \\
\hline $391 \mathrm{C}-10-2,108-111 \mathrm{~b}$ & 85 & - & - & - & - & - & - & - & - & - \\
\hline & 9 & - & - & - & - & - & - & - & - & - \\
\hline & 45 & 103 & 90 & 20 & 100 & 72 & 165 & 144 & 32 & 160 \\
\hline 3 & 4 & 75 & 76 & 17 & 66 & - & - & - & - & - \\
\hline $391 \mathrm{C}-26-2,63-65$ & 22 & 15 & 78 & 12 & 30 & 40 & 26 & 132 & 27 & 51 \\
\hline $391 c-45-3,71-77$ & 15 & 14 & 40 & 12 & 12 & 79 & 75 & 212 & 64 & 64 \\
\hline $391 \mathrm{C}-46-1,139-142$ & 20 & 76 & 102 & 32 & 86 & 23 & 86 & 116 & 36 & 97 \\
\hline $391 \mathrm{C}-$ & 16 & 52 & 72 & 24 & 35 & - & - & - & - & - \\
\hline & 68 & 80 & 132 & 27 & 130 & 73 & 88 & 144 & 30 & 148 \\
\hline $391 \mathrm{c}-49-2,137-139 \mathrm{~b}$ & 74 & 76 & 126 & 33 & 90 & 91 & 93 & 155 & 40 & 113 \\
\hline $391 \mathrm{C}-50-1,118-120$ & 46 & 54 & 75 & 23 & 38 & 80 & 95 & 131 & 41 & 67 \\
\hline $391 C-52-2,103-106$ & 65 & 96 & 118 & 45 & 88 & 80 & 117 & 144 & 54 & 108 \\
\hline
\end{tabular}

Note: $\mathrm{b}=$ brown layer $; \mathrm{g}=$ gray layer $; \mathrm{bl}=$ black layer.

Black and gray claystones and the claystone interbeds in limestones contain more $\mathrm{SiO}_{2}$ and less $\mathrm{Al}_{2} \mathrm{O}_{3}$. The $\mathrm{SiO}_{2} / \mathrm{Al}_{2} \mathrm{O}_{3}$ ratio ranges from 3.5 to 4.1 . Higher $\mathrm{MgO}$ and $\mathrm{K}_{2} \mathrm{O}$ concentrations, as compared with variegated claystone, were also detected.

The Upper Jurassic red marl is slightly higher in $\mathrm{SiO}_{2}$ relative to $\mathrm{Al}_{2} \mathrm{O}_{3}\left(\mathrm{SiO}_{2} / \mathrm{Al}_{2} \mathrm{O}_{3}\right.$ ratio 4.0-4.7). Some authigenic silicification must have occurred. The higher $\mathrm{MgO}$ content (if calculated on carbonate-free basis) may suggest a higher montmorillonite content, but diagenetic dolomitization is a possible alternative explanation. Dolomite crystals were identified in thin sections.

\section{DISCUSSION}

We infer the following geochemical characteristics of the main lithologies from the data.
The Pleistocene hemipelagic clay and silty clay, drilled at Site 388 on the lower continental rise and at Site 391 in the Blake-Bahama Basin, are composed of fine-grained terrigenous components. The iron content (carbonate-free basis) ranges from 4.04 per cent to 5.15 per cent; titanium ranges from 0.42 per cent to 1.05 per cent; the $\mathrm{Fe} / \mathrm{Ti}$ ratio from 0.42 to 10.88 . Some relatively high titanium values are probably related to terrigenous titanium-bearing heavy minerals. The manganese concentration is low $(0.04 \%$ to $0.12 \%)$ indicating that it was diagenetically removed in reducing conditions. Trace elements are within the limits common for terrigenous sediments.

The calcareous and marly oozes are remarkably variable in iron and some trace element contents, and less so in manganese and titanium contents. Along with dilution by biogenic $\mathrm{CaCO}_{3}$, the variations occur in the 
TABLE 5

Bulk Chemical Composition (\%) of the Leg 44 Sediments (X-ray Fluorescence Analysis)

\begin{tabular}{|c|c|c|c|c|c|c|c|c|c|c|}
\hline $\begin{array}{c}\text { Sample } \\
\text { (Interval in } \mathrm{cm} \text { ) }\end{array}$ & $\mathrm{SiO}_{2}$ & $\mathrm{TiO}_{2}$ & $\mathrm{AI}_{2} \mathrm{O}_{3}$ & $\mathrm{Fe}_{2} \mathrm{O}_{3}$ & $\mathrm{MnO}$ & $\mathrm{MgO}$ & $\mathrm{CaO}$ & $\mathrm{K}_{2} \mathrm{O}$ & i.1. & $\mathrm{SiO}_{2} / \mathrm{Al}_{2} \mathrm{O}_{3}$ \\
\hline $391 \mathrm{~A}-17-4,139-142$ & 46.4 & 0.32 & 9.24 & 2.97 & 0.05 & 3.21 & 14.69 & 1.02 & 19.9 & 5.0 \\
\hline $391 \mathrm{~A}-20-2,54-57$ & 60.3 & 0.58 & 12.69 & 6.17 & 0.03 & 3.48 & 0.77 & 1.69 & 13.1 & 4.8 \\
\hline $391 A-21-1,63-67$ & 55.8 & 0.97 & 18.12 & 8.00 & 0.12 & 2.15 & 0.47 & 2.69 & 10.3 & 3.1 \\
\hline $391 \mathrm{~A}-21-1,75-79$ & 54.0 & 0.93 & 17.95 & 8.48 & 0.79 & 1.79 & 0.60 & 2.69 & 10.2 & 3.0 \\
\hline $391 \mathrm{~A}-21-2,88-89$ & 49.3 & 0.86 & 16.45 & 16.00 & 0.12 & 2.16 & 0.52 & 2.80 & 11.6 & 3.0 \\
\hline $391 \mathrm{~A}-21-3,93-96$ & 54.4 & 0.84 & 16.46 & 10.21 & 0.05 & 1.49 & 0.42 & 2.86 & 12.0 & 3.3 \\
\hline $391 \mathrm{~A}-21-5,8-10$ & 52.7 & 0.91 & 18.46 & 7.11 & 0.04 & 2.94 & 0.54 & 2.53 & 11.6 & 2.8 \\
\hline $391 C-2-1,6-10$ & 21.1 & 0.06 & 4.00 & 1.62 & 0.02 & 2.23 & 35.93 & 0.02 & 35.5 & 5.3 \\
\hline $391 C-4-1,107-110$ & 54.1 & 0.88 & 17.89 & 8.09 & 0.04 & 2.74 & 0.52 & 2.47 & 12.3 & 3.0 \\
\hline $391 C-5-1,72-75$ & 53.1 & 0.90 & 17.19 & 10.49 & 0.10 & 2.43 & 0.65 & 2.84 & 9.6 & 3.1 \\
\hline $391 C-6-1,56-61$ & 56.2 & 0.88 & 17.27 & 10.33 & 0.04 & 1.68 & 0.52 & 2.83 & 8.6 & 3.2 \\
\hline $391 C-10-1,72-75$ & 56.0 & 0.80 & 15.98 & 7.94 & 0.04 & 2.83 & 0.60 & 2.60 & 12.2 & 3.5 \\
\hline $391 \mathrm{C}-10-2,108-111$ & 54.0 & 0.76 & 14.85 & 11.34 & 0.10 & 2.92 & 0.47 & 3.18 & 10.0 & 3.6 \\
\hline $391 \mathrm{C}-15-3,83-86$ & 45.9 & 0.53 & 11.69 & 5.16 & 0.03 & 3.39 & 9.67 & 2.62 & 17.4 & 3.9 \\
\hline $391 C-28-2,106-110$ & 46.6 & 0.58 & 11.45 & 5.94 & 0.02 & 2.99 & 11.04 & 1.93 & 16.7 & 4.1 \\
\hline $391 C-49-2,81-83$ & 41.8 & 0.32 & 8.94 & 4.64 & 0.05 & 3.19 & 16.74 & 1.70 & 20.3 & 4.7 \\
\hline $391 C-52-4,13-15$ & 41.2 & 0.44 & 10.37 & 7.06 & 0.06 & 3.45 & 13.33 & 2.29 & 19.2 & 4.0 \\
\hline
\end{tabular}

carbonate-free basis, as well. The carbonate-free residue of foraminifer sand on the Recent sea bottom at Site 389 contains as much as 10.51 per cent iron and 0.41 per cent manganese; nickel content is $614 \mathrm{ppm}$. Relatively high copper and zinc values were detected. The enrichment may be explained by precipitation of $\mathrm{Fe}$ hydroxide and subsequent sorption of the minor elements from the seawater in the slow accumulation or non-depositional environment. The presence of manganese nodules confirms this assumption.

Eocene nannofossil ooze (Site 390, carbonate-free basis) is low in iron. The titanium and the trace element contents are similar to that of hemipelagic clay. The manganese content is slightly higher. In contrast, the Cretaceous variegated and brown marly oozes are higher in iron (up to $8.38 \%$ in a yellowish red interbed). The titanium content ranges from 0.38 per cent to 1.01 per cent and there is no relationship between iron and titanium, which results in wide variations in the $\mathrm{Fe} / \mathrm{Ti}$ ratio. Apparently different sources of iron and titanium are responsible for the relative abundances. Titanium occurs mostly in clastic sediments, whereas iron, where enriched, seems to be contributed by hydrogenous or diagenetic processes resulting in its precipitation as a hydroxide from seawater or interstitial water. In any case, the iron-rich layers probably accumulated at slow rates. The manganese content is unusually low for the oxidized sediments $(0.02 \%$ to $0.19 \%)$. Copper is low, nickel and cromium are within the limits common for hemipelagic, rather than pelagic, sediments.

Miocene intraclastic chalk and radiolarian mudstone (Site 391, unit 2; see Figure 1) are both low in iron and titanium, even on a carbonate-free basis. This is probably due to dilution by biogenic silica (radiolarians).

The Cretaceous black and gray claystone sequence at Site 391 (unit 3) is geochemically variable. The iron content ranges from 3.58 per cent to 16.53 per cent. Manganese from 0.01 per cent to 4.25 per cent, titanium from 0.30 per cent to 1.32 per cent, aluminum from 3.8 per cent to 11.5 per cent, copper from $30 \mathrm{ppm}$ to 235 . These ranges approximate the range of all Leg 44 sediments taken together (on carbonate-free basis). Three intervals of variegated claystone differ notably from other alternating black and gray layers (see Figure 1). Two of these (Hole 391A, Core 21 and Hole 391C, Core 10$)$ are enriched in titanium (1.05\% to $1.32 \%)$ and show low $\mathrm{Al} / \mathrm{Ti}$ ratios. The iron content is relatively high $(4.90 \%$ to $8.82 \%)$ in the brown and red interbeds of these intervals, but the high titanium content results in a rather low $\mathrm{Fe} / \mathrm{Ti}$ ratio. A high zinc content is characteristic for the intervals, the maximum values occurring in the black interbeds. The aluminum content is high throughout unit 3 , except in the sideritic interbeds and shows no clear relationship among the different color layers. The increased aluminum content probably came from an aluminum-rich terrigenous source, whereas variations in iron, manganese, and zinc were produced during diagenetic migration of the elements in contrasting redox conditions. The highest concentration of iron occurs where authigenic siderite was formed. Some of the iron is present in pyrite and the zinc is probably present in sulfides. Some of the manganese is present in rhodochrosite and/or manganiferous siderite.

Similar geochemical features appear in the unit 4 calcareous rocks, if considered on a carbonate-free basis. Pyrite- and siderite-bearing limestones, marly limestones, and calcareous claystones show a $\mathrm{Fe} / \mathrm{Ti}$ ratio higher than 10 (up to 54 in a high-calcareous sample). The aluminum content is somewhat high and consequently the $\mathrm{Fe} / \mathrm{Al}$ ratio is relatively low. Some relatively high manganese values are probably associated with the authigenic rhodochrosite.

Upper Jurassic red and pink marly limestones and calcareous claystones are relatively rich in iron $(4.78 \%$ to $7.75 \%$ on carbonate-free basis), but no concentrations similar to those of "metalliferous" sediments were found. The manganese content is rather low, except for a single sample of a very dark brown interbed. The $\mathrm{Fe} / \mathrm{Al}$ ratio is similar to this in unit 4, and the $\mathrm{Fe} / \mathrm{Ti}$ ratio is even lower (see Figure 1). No 
significant increase in trace elements has been discovered. Therefore, the "metalliferous" zone in unit 5 is rather weak if present at all. The red color and higher iron content are more likely related to a pelagic environment with low sediment accumulation rates.

\section{REFERENCES}

Bischoff, J.L., 1969. Red Sea geothermal Brine deposits-their mineralogy, chemistry and genesis. In Degens, E.T., Ross, D.A. (Eds.), Hot brines and Recent heavy metal deposits in the Red Sea: New York (SpringerVerlag).

Boström, K. and Peterson, M.N.A., 1969. The origin of aluminum-poor ferromanganoan sediments in areas of high heat-flow on the East Pacific Rise: Marine Geol., v. 7, p. 427.

Boström, K., Peterson, M.N.A., Joensu, O., and Fisher, D.E., 1969. Aluminum-poor ferromanganoan sediments on active oceanic ridges: J. Geophys. Res.., v. 74, p. 3261.
Lancelot, Y., Hathaway, J.C., and Hollister, C.D., 1972. Lithology of sediments from the Western North Atlantic Leg 11 Deep Sea Drilling Project. In Hollister, C.D., Ewing, J.I., et al., Initial Reports of the Deep Sea Drilling Project, Volume 11: Washington (U.S. Government Printing Office), p. 901-948.

Lisitzyn, A.P., Bogdanov, Y.A., Murdmaa, I.O., Serova, V.V., Zverinskaya, I.D., Lebedev, A.I., Lukashin, V.N., and Gordeev, V.V., 1976. Metalliferous sediments and their genesis. In Geological-Geophysical Researches in the South-Eastern part of the Pacific Ocean. Oceanological Res. No. 29. Results of Res. on the Internat. Geophys. Projects: Moscow (Nauka), p. 289-379.

Skornyakova, N.S., 1976. Dispersed Fe, Mn, Ti and several minor elements in the Pacific sediments. In Bezrukov, P.L. (Ed.): Ferromanganese nodules of the Pacific Ocean, Chapter VI: Moscow (Nauka), p. 168-181.

Strakhov, N.M., 1976. Problems of Geochemistry of Recent oceanic lithogenesis: USSR Acad. Sci. Geol. Institute, Trans., v. 292: Moscow (Nauka), p. 299. 